\title{
Creating a Favourable environment For Managing Innovation In Organization
}

\author{
Akintan Olumide Oluayo, Akin Marsap \\ Graduate Institute of Social Sciences, Department of Business Administratıon, Istanbul Aydin University, Beşyol Mh., \\ 34295 Küçükçekmece/listanbul, Turkey.(2014) \\ Email: olumide_oluayo2000@yahoo.com \\ Prof Dr. Akin Marsap \\ Supervisor/Lecturer:Graduate Institute of Social Sciences, Department of Business Administratıon, Istanbul Aydin \\ University, Beşyol Mh., 34295 Küçükçekmece/İstanbul, Turkey.(2014)
}

\section{Email: akinmarsap@aydin.edu.tr}

\begin{abstract}
The research on innovation had been a vast field that have drawn a lot of thinking and also creativity. The condition necessary for forming a favorable environment in the most of organisation is just a light reflecting to the proposed pathway a company can utilize so as to attaining success in innovation. Innovation according to Austrian Economist Joseph Schumpeter outlined in (The theory of economic development) where he proposed 5 types of innovation. Product, Process, Business, Source of supply, Mergers and divestment.

There have been alot of works on innovation which lead to addition types of innovation. To understand the topic innovation, one must be able to also comprehend the some key components of innovation, the nature of innovation, the importance, the stages of Innovation, the categories innovation, the drivers of innovation. The strategies that we can use to motivate members is also neccessary.

Further, an extensive research was conducted that lead to the proponent of six conditions that can favour the management of innovation in organisations as: The importance of teamwork and the involvement of every employee, the importance of management participation, the importance of effective communication and information flow, the importance of an innovative culture, the importance of the employees "vocational training", the importace of employee's role integration around specialties and process rather than department.
\end{abstract}

Keywords: Innovation, stages, categories, nature, drivers, motivation, and favourable.

\section{Academic Discipline and Sub-Disciplines}

History; Education; Sociology; Psychology; Cultural Studies;

Business Management;

\section{SUBJECT CLASSIFICATION}

Strategic Management; Financial Accounting; Modern Management;

TYPE (METHOD/APPROACH)

Quantitative Analysis; Inductive and Deductive method; Ground Theory; Questionaire/Interview.

\section{Council for Innovative Research}

Peer Review Research Publishing System

Journal: International Journal Of Management \& Information Technology

Vol. 10, No 4

editorsijmit@gmail.com

www.jimit.com 


\section{INTRODUCTION}

An innovative organization is no doubt is a competent organization. It improves in either its product or service quality, therefore thrieves in a competitive market situation. Therefore, any organisation that have the ability and characteristics to channel creativity and comeout with useful and valuable results is referred to as innovative organisation. When managers mention changing an organisation to enhanced creative, it simply implies stimulation and nurturing of innovation.

Creativity can be seen as ability to merge ideas in a different way or making significant relations among ideas. In essence, crativity provides new ideas useful for quality improvement in organisation and to put the idea into action (Samuel, 2000: 519 - 522). Innovations play a significant role in the life of companies and its critical to the long-run success of virtually any organisation. This statement can be termed as an postulate, which, as we know, it does not call for a verification. The managers have defined innovation in different ways;

Innovation can be defined as creation of new ideas, product, services, or processes via the improvement, discovery or invention (Stewart and Lyman, 2000:146).

In another management textbook by Pearson; he defined innovation as when new ideas are been introduced to improve the organisational process, product, or service (Samuel and Trevis, 2012: 487).

As found in Oxford"s Dictionary of Business and Management innovation is been defined as; innovation was seen as when an innovator or his company a upper hand over his rivals or competitors via using a new approach to designing, producing, or marketing goods (Oxford online Reference. 2013).

The initial natural form of occurrence of innovation is as an idea which is later transformed into innovation. The process requires some factors or agent to be implemented. Innovation must be well comprehended not to be an easy task as it also have its cons and prons. The establishment of a stable and condusive environment for this changes, in other to achieve the aims and objectives of the management system is part of the focus of this study. The anticipation of likeable problems that may surface during this process and applying best strategies to solving such banes efficiently.

\section{HISTORY AND TYPES OF INNOVATION}

Their is a long history behind innovation. Early researches done on innovation had majorly addressed the organisation's ability to respond and cope with both external and internal changes (Burns and Stalker 1961; Hull and Hage 1982). Additional works have helped to differenciate and clarify innovation. Promotion of both process and product innovation have recieved reasonable emphasis irrespective of the need for change instantly (Kanter 1988). It is no longer sufficient for an organisation ability to promote process and product innovation, as such a third type of innovation has been introduced called Strategy innovation or business concept innovation. The invention of strategy or business concept innovation was as a result of the insufficiency of organisation to promote process and product innovation.

The concept behind innovation is now more complicated in some other different ways as well. The first major scholar Joseph Schumpeter that address innovation in 1911 (The theory of economic development) where he proposed 5 types ( Thomas, 2007: 4 -5):

A. Product innovation: It can be defined as the introduction of a new good - it must be one with which consumers do not know yet - or of a new quality of a good.

B. Process innovation: It means introducing new means of production, which have not yet been tested via experience from the point of manufacture concerned.

C. Business model: It means opening a new market, a market into which certain branch of manufacture of a country in question have not yet ventured into previously, whether the market existed or never existed

D. Source of supply:It means acquiring a new source of supply of raw materials which could be half of the manufactured goods, again it is inconsequential if this source existed or has to be first created.

E. Mergers \& divestments:it involves the process of new organisation of any industry, i.e monopoly position creation (for example through trustification) monopoly position breaking up.

F. Marketing innovations: As already known that it is a discipline, has been changing the background knowledge in the social science which serves as its backup is also changing. It is comprised of (e.g price, quality, and bahavior data, understanding of human bahaviour from psychology, anthropology and sociology ( C-suite insider, 2014).

G. Organisational innovations: The introduction and application of a new method of doing business practise, external relations, workplace organisation innovation. Changes in the three above mentioned are all based on the organisational method already in use. The changes that occur due to the following factors prices, commission, selling out new or important poduct are not usually termed as innovation (Journal of European union, 2006).

H. Supply chain innovations: Supply chain innovation is important for companies of all sizes. It means looking at the way a company applies its assets, operating resources, and capabilities to develop new ways to satisfy customer needs (Leslie, 2006). 
I. Substantial innovations: Provides greater opportunity to value-add as it engenders the creation of business opportunities that are likely to lead the industry and provide a competitive advantage to the company developing them. This level of innovation requires considerable investment in the process and an effective strategy for managing the innovation from its gestation and development period through to successful commercialisation (CEO forum, 2014):

J. Financial innovations: Financial innovation can be defined as the act of creating and then popularising New financial instruments as well as new financial technologies, institutions and markets. It includes institutional, product and process innovation.

K. Institutional innovations: Relate to the creation of new types of financial firms (such as specialist credit card firms like MBNA, discount broking firms such as Charles Schwab, internet banks and so on); (Financial times, 2014).

L. Incremental Innovations: Incremental product innovation concerns an existing product whose performance has been significantly enhanced or upgraded. This again can take two forms. A simple product may be improved (in terms of improved performance or lower cost) through use of higher performance components or materials, or a complex product which consists of a number of integrated technical subsystems may be improved by partial changes to one of the subsystems (OECD Frascati Manual, 2013).

M. Breakthrough /Radical Innovation: It can be also termed as the radical innovation, as it has been stated above. It is a vital point for the two kinds of innovations and it is difficult to differentiate them. Although, differentiation can be done easily theoretically but practically tougher than it actually appears (Katz, 2009).

N. Transformational Innovation: This is usually (but not always) the introduction of a technology that creates a new industry and transforms the way we live and work. This kind of innovation often eliminates existing industries or, at a minimum, totally transforms them.

\section{NATURE OF INNOVATION}

It is very vital the nature of innovations is being properly understood and discussed by the innovative organisation. venturing into innovation is very critical and their is huge potential of failure if not properly done. Without effectively innovating, it will be at the detriment of the organisations survival because they really put little attention to significance of the issue of innovation process and effectively. This nature can be associated with some of the mention characteristics below:

A. Innovation usually plays a key roles in reshaping productivity

B. Most innovation results from previous product or ideas.

C. Innovation is pervasive throughout the economic system

D. Most innovative change is a gradual process

E. Radical changes are rare and largely unknowable - most changes in knowledge and technology are evolutionary

\section{THE IMPORTANCE OF INNOVATION}

In order for us to understand the need for innovaqtion. It will be essential to find answers to this important questions:
A. Why is it important to innovate
B. What happens when a company does not innovate

\section{INNOVATION IN THE MODERN MANAGEMENT}

Defining innovation from the modern management viewpoint; "Innovation can be defined as a process of using a new idea to the improve processes, products, or services in an organisation (Samuel and Trevis, 2012: 483 - 487)"

As the term broadened, there have been deeper insight and broader understanding on innovation. Christensen gave a deeper insight on the concept of innovation by resolving into newness and impact. Which he analysed in his publication, into three main types of innovation (process, product or service, and strategy), each of which can vary in terms of the degree of Newness (incremental to radical) and also the Impact (sustaining/discontinuous); (Donald et al, 2012: 45).

Henderson and Clark in 1990, used the differentiation model base where he clarified component and system knowledge to differentiate four various kinds or classes of innovation, this is illustrated in the (Tabl 1) i.e system changes. (Henderson and clark, 1990): 
Table 1: The four categories of Innovation, component changes and system changes (Henderson and Clark, 1990).

\begin{tabular}{l|l|l|}
\multicolumn{1}{c|}{ Overtuned } & \multicolumn{1}{c|}{ Reinforced } \\
\cline { 2 - 3 } inchange & $\begin{array}{l}\text { Incremental } \\
\text { Innovation }\end{array}$ \\
\hline $\begin{array}{l}\text { Modular } \\
\text { Innovation }\end{array}$ & $\begin{array}{l}\text { Architectural } \\
\text { Innovation }\end{array}$ \\
\cline { 2 - 3 } change & $\begin{array}{l}\text { Radical } \\
\text { Innovation }\end{array}$ &
\end{tabular}

From the above analysis, radical and incremental innovation are separated as two opposite extremes. Although, two new intermediate stages between them is been introduced as shown in (Table 2) below, they are modular innovation and architecturalinnovation (Henderson and clark, 1990):

Table 2: Analysis of the changes revolved with types of Innovation (Henderson and Clark, 1990).

\begin{tabular}{|l|l|l|}
\hline Component & Innovation & System \\
\hline Improved & Incremental & Indifferent \\
\hline New & Modular & Indifferent \\
\hline Improved & Architectural & $\begin{array}{l}\text { Architecture/New } \\
\text { Configuration }\end{array}$ \\
\hline New & Radical & Architecture/New \\
& & Configuration \\
\hline
\end{tabular}

The next discrepancy below is for radical and increase innovations. The term incremental innovations means product and services are been improved on. On the Contrary, radical innovations means completely new technologies should be established or be combined with the previous old ones. The big difference majorly in this case is that there are no improvements being done whatsoever.

\section{STAGES OF INNOVATION}

The number of settings in which innovation occurs is also increasing. To effectively manage innovation, it will require that we understand how it is accepted in the organisations. Researchers suggest a five steps process to describe the life cycle, or stages, of innovation in business (Stewart, 2000: 160 -165):
A. Invention: it is the creation of new idea or process, but invention is not the same as innovation.
B. Development:It involves taking the invention and making it practical for some purpose or Market.
C. Diffusion:It is the third stage and it is the process of getting the innovation into use by end users or customers.
D. Integration:Refers to the process of making the change permanent in the organisation.
E. Decline:It is the last and fifth stage of innovation when the innovation stops being used.

\section{DRIVERS OF INNOVATION}

Usually cost minimisation has adequately been a major driver of innovation, this does not therefore render other drivers less significant. Some measures have been frequently showing such regulatory factors stood as drivers of innovation in the Past several decades. In addition to this, the need therefore to promote the image helps and it has been related to environmental and sustainable development innovations. Having a good image therefore promotes both the customer loyalty and the companyies strategies towards growth. Some of the primary drivers of innovation include (Hamel, 1996):
A. Financial pressures to decrease costs, increase efficiency, do more with less.
B. Increased competition.
C. Shorter product life cycles. 

D. Value migration.
E. Stricter regulations.
F. Industry and community needs for sustainable development.
G. Increased demand for accountability.
H. Community and social expectations and pressures (giving back to the community, doing good) etc.
I. Demographic, social, and market changes.
J. Rising customer expectations regarding service and quality.

From a Quanlitative research on the Conditions for managing a favourable for managing innovation in an organisation. The research was been carriedout in Twenty both Turkisk and English companies. The datas were gather via the use method know as Ground Theory.

The aim of this work was basically to Test the Hypothesis; Effect of the conditions on forming a favourable environment for managing in innovation in an organisation.

The research work started with the first four conditions extracted from past literatures and in conclusssion, after the study ws modified with two other factors that emerged.

\section{CONDITIONS FOR FAVOURABLE ENVIRONMENT IN ORGANISATION.}

From an extentensive research on literaures, and interviews on this field. The conditions been highlighted below have been compilled as to be able to facilitate an environment where innovation in organisation would occur:

1. The importance of teamwork and the involvement of every employee

2. The importance of management participation

3. The importance of effective communication and information flow

4. The importance of an innovative culture

5. The importance of the employees "vocational training"

6. The importace of employee's role integration around specialties and process rather than department.

\section{ACKNOWLEDGMENTS}

Thanks to everyone who had contributed to the success of this work. My entire family Edward Oladokun, very loving precious mother Roseline Olubukola, siblings Olatokunbo, Yetunde, Abimbola, Olayinka, Oyewole, Racheal and others for the unconditional love, support financially and physically, you mean the world to me. I also send gratitudes to S. Agboola Akintan, a wonderful Grand mother Mrs Soile Akintan in loving memory, friends and colleagues. I love you all and I will forever be greatful for the love.

\section{REFERENCE}

1. Burns, T and George S.M (1961). The management of innovation. London.Tavistock. 4 (1961),

2. C - SUITE INSIDER (2014). Marketing-innovation. 6 April, 2014.

3. Ceoforum 2014. 14 Septerber, 2014

4. Donald A. Norman and Roberto V (2012). Incremental and radıcal innovatıon: Design research versus technology and meaning change, Politecnico di Milano and Mälardalen University (2012).

5. Financial Innovation (2014). The Financial Times, 4 April, 2014.

6. Henderson, R.M. and Clark, K.B (1990). Architectural innovation. The Reconfiguration of Existing Product Technologies and the Failure of Established Firms. Administrative Science Quarterly. (1990) 9 - 30.

7. Hamel, Gary (1996). "Leading the revolution” Boston. (1996). Harvard Business School Press

8. Hull, F.M, and Hage. J (1982) Organizing for innovation: Beyond the Burns and Stalker's Organic Type. Sociology

9. Kanter, R. M (1988) When a Thousand Flowers Bloom: Structural, Collective, and Social Conditions for Innovation in Organization. Research in organizational behavior .

10. Leslie H. H (2006). Thomas Publishing Company. .

11. Martins and Terblanche (2003). Building organisational culture that stimulates creativity and Innovation: European journal of innovation management.

12. OECD Frascati Manual (2013). Innovation in science, technology and industry. 4 April, 2014. 
13. Samuel C. C (200). Modern management: diversity, quality, ethics, and global environment. New Jersey. USA: Prentice Hall. 8. (2000) $519-522$.

14. Samuel C. C and Trevis S. C. Modern management: concept and skills New Jersey. USA: Prentice Hall. Pearson 12. (2012) $483-490$.

15. Stewart J. B and Lyman. W P (2000). Management: meeting new challenges New jersey. USA: Prentice Hall 1. (2000) 146 - 165.

16. Thomas. L.W and David J. H (2012) Strategic management and business policy: Towards global sustainability New Jersey. USA: Prentice Hall. Pearson, 13 (2012) 279

17. KATZ. R (2009). Innovator's Toolkit. 10 Practical strategies to help you develop and implement innovation. Harvard Business Essentials., Boston. Harvard Business School Publishing.

\section{Biography}

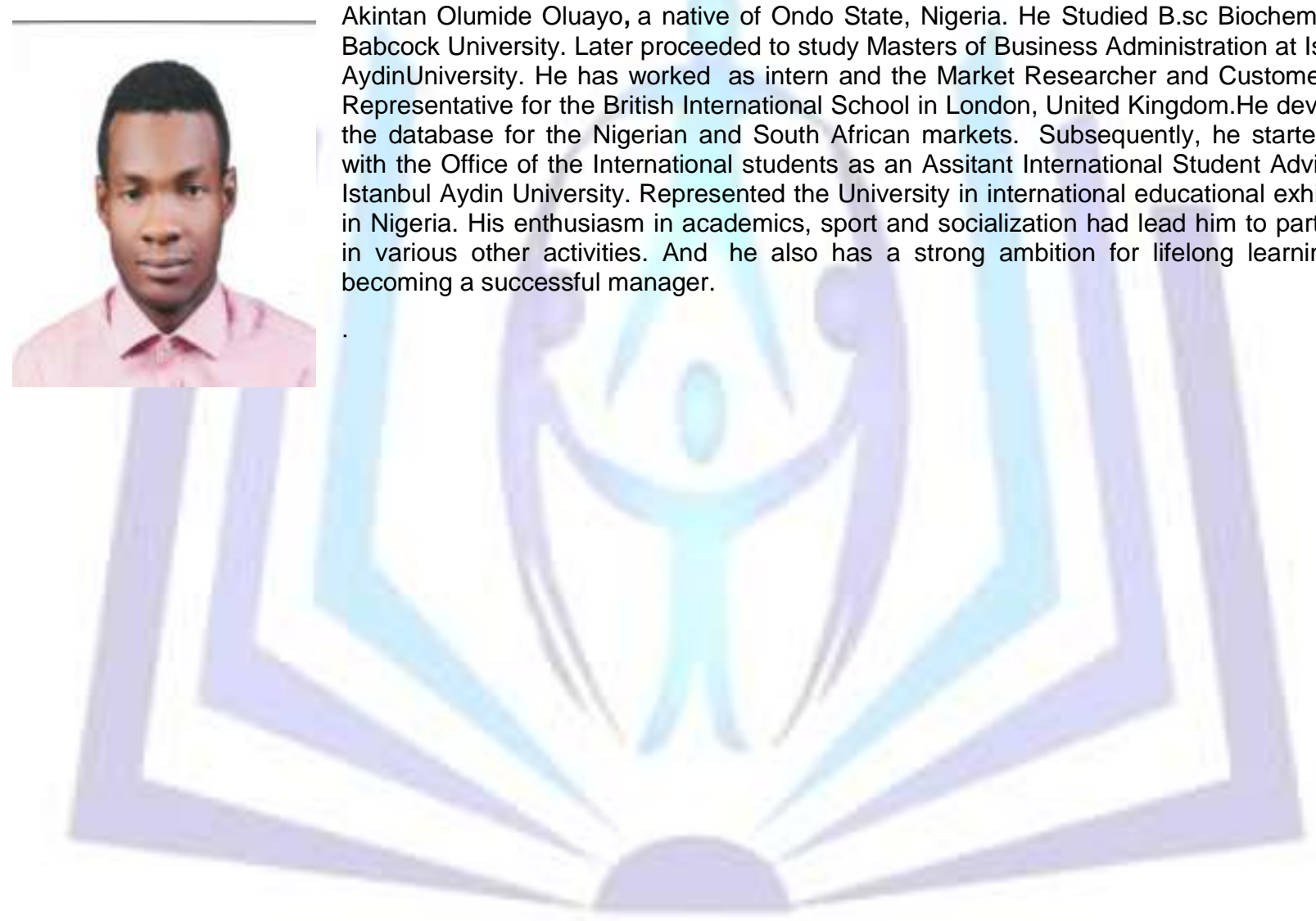

